\title{
Motorcycle accident injuries are more severe than other land transportation injuries
}

\author{
Woro Riyadina Djoeworo*, Dian Perwitasari Tasono Hadi*, \\ and Sulistyowati Tuminah Darjoko*
}

\begin{abstract}
\section{BACKGROUND}

Injuries due to traffic accidents are the leading cause of death and disability, especially in developing countries. The proportion of injuries in Indonesia tends to increase. The cause of the injury is dominated by motorcycle accidents (70-85\%). The aim of this study was to compare the severity of motorcycle injuries with that of other land transportation injuries in Indonesia.
\end{abstract}

\section{METHODS}

A study of a cross-sectional design was performed involving 15,849 subjects from 33 provinces in Indonesia. The dependent variable was the severity of injury and the main independent variable was transportation mode (motorcycle and other vehicles). Other independent variables included were respondent characteristics (sex, age, education, occupation, economic status) and health status (stroke, hypertension, heart disease, impaired hearing and vision). Chi-square test and multiple logistic regression were used to analyze the data.

\section{RESULTS}

The contribution of motorcycle transportation mode to the severity of the injury was $85.5 \%$. The proportion of severity of injury due to motorcycle transportation was higher $(9.0 \%)$ than to other land transportation modes (7.5\%). The severity of injuries related to motorcycle transportation was 1.1 times greater $(\mathrm{AOR}=1.195 \% \mathrm{CI} 1.0-1.3)$ than that other related to vehicles. The determinants of severity of injury due to motorcycle transportation were age and sex.

\section{CONCLUSION}

Motorcyclists are at higher risk of having injuries than persons using other modes of transportation. Motorcyclists need to increase the safety of riding and to be more discriminating in the selection of the safest mode of transportation, by taking age and sex into consideration.
*National Institute of Health Research and Development, Ministry of Health, Republic of Indonesia

Correspondence:

Woro Riyadina

National Institute of Health Research and Development,

Ministry of Health,

Republic of Indonesia Jalan Percetakan Negara No.29 Jakarta 10560 Kotak Pos 1226 Email:w.riyadina02@gmail.com Mobile : +6281297673074

Date of first submission, March 24, 2017

Date of final revised submission, June 21, 2018

Date of acceptance, June 25, 2018

This open access article is distributed under a Creative Commons AttributionNon Commercial-Share Alike 4.0 International License

Cite this article as: Djoeworo WR, Hadi DPT, Darjoko ST. Motorcycle accident injuries are more severe than other land transportation injuries. Univ Med 2018; 37:105-14. doi: 10.18051/UnivMed. 2018.v37.105-114

Keywords: Injury, severity, motorcycle, land transportation 


\section{INTRODUCTION}

Injuries due to land transportation are a challenging public health problem and are estimated to become the fifth main health problem globally in the year 2013.(1) More than two-thirds of cases of injury occur in developing countries. ${ }^{(1)}$ Mortality due to injury is projected to increase from 5.1 million to 8.4 million ( $9.2 \%$ of global mortality) and is estimated to rank third in disability -adjusted life years (DALYs) in the year 2020.(2) Injury ranks second as a cause of death in Indonesia. The problem of injury in developing countries causes an economic loss of $2 \%$ of the Gross Development Product (GDP), ${ }^{(3)}$ and the severity of injury contributes to $15-55 \%$ of deaths. ${ }^{(4)}$ Studies found that families of low economic status are at high risk for becoming poor after a family member experiences a transportation accident as compared with families of high economic status. ${ }^{(5)}$

Injury due to traffic or land transportation accidents is the main cause of death and general disability particularly in developing countries. The prevalence of injury shows an increasing trend from $25.9 \%$ in $2007{ }^{(6)}$ to $47.7 \%$ in $2013 .{ }^{(7)}$ In Indonesia the number of motorcyclists with unsafe riding behavior increases by $11 \%$ each year. ${ }^{(8)}$ The vehicles that contribute to around 70 $85 \%$ of the causes of land transportation injury are motorcycles. ${ }^{(9)}$ In Malaysia, $70 \%$ of accidents involve motorcycles, and accounts for $60 \%$ of all road fatalities. ${ }^{(10)}$ The results of the Basic Health Research survey (Riskesdas) for 2013 report the proportion of injury due to motorcycle transportation to be $40.6 \% .^{(7)}$ Disability and death due to injury are closely associated with the degree of severity experienced. Death due to injury from motorcycle transportation involving drivers and passengers account for $58.7 \%{ }^{(10)}$ The results of a study in Kenya show that motorcycles as a mode of public transport are the main cause of severity and death due to injury. ${ }^{(11)}$

There are three main principles in the prevention and control of injury, i.e. 1) reduce the probability of occurrence of injury (primary prevention), 2) reduce the severity of the injurious event (secondary prevention ) and 3) reduce the effects that occur after the injurious event (tertiary prevention). Primary prevention means the total elimination of the incidence of trauma so that it does not occur at all. Secondary prevention is the reduction of the severity of trauma that occurs. Tertiary prevention comprises the efforts carried out to reduce the consequences of trauma after it occurs, e.g. a trauma management system (coordination of emergencies, identification of the center of emergency and integration of rehabilitation services). ${ }^{(12)}$ These efforts at trauma prevention need information on the degree of severity of the injury experienced, especially that due to land transportation.

Studies in Nigeria report that motorcycles account for $67 \%$ of all traffic accident victims who are referred to hospitals (13) while in Tanzania the total is $37.2 \%$. $^{(14)}$ In Thailand, a total of $80 \%$ of victims of motorcycle transport accidents who are referred to hospitals have head injuries. ${ }^{(15)}$ The results of one study state that motorcycle drivers are at 26 -fold greater risk of dying from accidents as compared with car drivers, and at 5-fold greater risk of injury. The degree of severity of injury of drivers due to motorcycle accidents is 6 times more severe than that of car passengers. ${ }^{(16)}$

Several studies have shown consistent results, in that motorcycle accidents are the largest contributors to the incidence of land transportation injury and cause more severe injury compared to other modes of land transportation. However, there are not many analytical studies on the degree of severity of injury by combining the parts of the body affected by injury and the type of wounds based on the criteria of the 10th edition of the International Classification of Diseases (ICD). ${ }^{(17)}$ The increasing trend in the incidence of land transportation accidents and injuries, particularly those caused by motorcycles, results in the need for comparative information on the degree of 
severity of injury due to motorcycles and other modes of land transportation. The aim of the present study was to compare the degree of severity of injury due to motorcycles and other land transportation modes.

\section{METHODS}

\section{Research design}

The present study was an observational study of cross-sectional design that used secondary data from Riskesdas 2013 for 33 provinces and was conducted from January to December 2014.

\section{Study subjects}

The subjects of the present study were residents who had ever experienced land transportation injury. The inclusion criteria were the completeness of data for the dependent and independent variables, while the exclusion criterion was the presence of extreme data (outliers), e.g. when there were wounds on all parts of the body (recall data). The sample size was based on public health data from 33 provinces, which were the data of the Riskesdas 2013 survey that fulfilled the inclusion and exclusion criteria and were ready for analysis. The sample of 15,894 persons was the sample size calculated with Lemeshow's formula for estimation of proportions, ${ }^{(18)}$ with a proportion of land transportation injury of $7.7 \%{ }^{(6)}$

\section{Measurements}

All variables were collected from interviews using structured questionnaires in accordance with the Riskesdas 2013 data collection guidelines. ${ }^{(19)}$ Injury was defined as the physical damage to the human body caused by forces that could not be tolerated and could not be foreseen. ${ }^{(20)}$ The cases of injury were obtained from interviews. The injuries asked were events that the respondents of all ages experienced during the last 12 months. Injury in Riskesdas was defined as the experiencing of injury causing disturbance of daily activities. For cases of injury in which the event occurs more than once in 12 months, the case of injury asked was the most severe one according to the respondent's statement. Especially for the variables of vision and hearing impairments, physical examination was performed according to the Guidelines for Biomedical Measurement and Examination (Pedoman Pengukuran dan Pemeriksaan Biomedis) of Riskesdas 2013. ${ }^{(21)}$

In the present study, the severity of the injury was a combination of two variables, i.e. the body part involved in the injury and the type of injury, that are further categorized into severe and non-severe injury according to the criteria of diagnostic classification of injury of ICD10. ${ }^{(15)}$ The injury was categorized as severe if the number of injured body parts was 4 out of 6 (head-neck, breast-back, abdomen-waist-hip, upper extremity/hand, lower extremity/leg), or if the injury was in the form of fractures or concussion or amputation of an extremity.

With regard to the characteristics of the respondents (age, sex, education, employment and economic status), age was categorized into 8 age groups $(0-4 ; 5-14 ; 15-24 ; 25-34 ; 35-44$; $45-54$; 55-64; >65 years), while sex was categorized into male and female. Educational level was categorized into 3 groups, i.e. low (no schooling - elementary school - junior high school) middle (senior high school); high (diploma - tertiary education). Employment was categorized into 6 groups, i.e. not yet employed ( $<10 \mathrm{yr})$, unemployed ( $\geq 10 \mathrm{yr})$, employed (government, private business, police), entrepreneur, farmer/laborer/fishermen, and other. Economic status was categorized into quintiles 1-5. Quintiles were calculated based on the conversion of assets according to the categories of the Central Statistics Agency (BPS). There were 2 types of disease that were analyzed, i.e. stroke and coronary heart disease, each with the categories yes and no. There were 2 types of impairment of the special senses that were analyzed, i.e. vision and hearing impairments, each with the categories yes and no. 


\section{Data analysis}

Differences in severity of injury due to motorcycles in comparison with other land transportation were analyzed with the chi-square test. The risk of severity of injury in relation to other factors was determined by multivariate analysis using the multiple logistic regression test. Data were analyzed by means of the SPSS program, at level of significance $\mathrm{p}<0.05$ and $95 \%$ confidence interval.

\section{Ethical clearance}

This study used secondary data from Riskesdas 2013, which received ethical clearance from the Commission for Health Research Ethics (Komisi Etik Penelitian Kesehatan, KEPK) of the Agency for Health Research and Development (Badan Penelitian dan Pengembangan Kesehatan, Balitbangkes), Ministry of Health, Republic of Indonesia (Kemenkes RI) under no. LB.02.01/5.2/KE.006/ 2013.

\section{RESULTS}

The different proportions of the severity of injury according to the mode of transportation are presented in Table 1 . The number of data analyzed was 15,894 , divided into injury due to motorcycles with 13,524 data (85.09\%) and injury due to other land transportation with 2,370 (14.91\%). Subjects with severe injury due to motorcycles were 1,214 in number $(9.0 \%)$ and that due to other land transportation $178(7.5 \%)$. Of all 1,392 cases with severe injury (8.8\%), injury caused by motorcycles accounted for 1214 $(9.0 \%)$, which was significantly higher than that caused by other land transportation, with 178 cases $(7.5 \%)(p=0.021)$. A comparison of the proportions of the severity of injury between motorcycles and other land transportation, by subject characteristic, may be seen in Table 2 .

There were significant differences in the proportions of the severity of injury due to motorcycles in comparison with other land transportation for the following respondent characteristics, i.e. age group, educational level, type of employment, and economic status. The proportion of severity of injury by age group showed significant differences $(\mathrm{p}<0.05)$ in the age groups of 5-14, 25-34, and 35-44 years, respectively. The proportion of severity of injury due to motorcycles appeared to be higher in the age group of 5-14 years as compared with injury due to other land transportation. On the other hand, in the age groups of 25-34 and 35-44 years, the proportion of severity of injury was greater in other land transportation as compared with motorcycles. The proportion of severe injury due to motorcycles in both sexes was higher than the severity due to other land transportation. In comparing the degree of severity of motorcycle accidents in both sexes, it appears that the severity of the injury was higher in males than in females, although the difference was not significant. Based on educational level, a significantly different proportion of severity of injury due to motorcycles as compared with other land transportation was seen with low education (no schooling-elementary school), whereas with higher educational level there was no difference. The employment status of "not yet employed (children)" showed a significant difference $(p<0.021)$ for the severity of injury due to motorcycles as compared with other land transportation.

Table 1. Distribution of severity of injury due to motorcycles and other land transportation modes $(n=15,894)$

\begin{tabular}{lccc}
\hline \multicolumn{1}{c}{ Mode of transportation } & \multicolumn{2}{c}{ Severity of injury } & \multirow{2}{*}{ p value } \\
\cline { 2 - 3 } & $\begin{array}{c}\text { Severe } \\
(\mathbf{n = 1 , 3 9 2 )}\end{array}$ & $\begin{array}{c}\text { Not severe } \\
(\mathbf{n}=\mathbf{1 4 , 5 0 2})\end{array}$ & $12310(91.0 \%)$ \\
\hline Motorcycles $(\mathrm{n}=13,524)$ & $1214(9.0 \%)$ & $2192(92.5 \%)$ & 0.021 \\
Other land transportation $(\mathrm{n}=2,370)$ & $178(7.5 \%)$ & 2190 \\
\hline
\end{tabular}


Table 2. Distribution of severity of injury due to motorcycles and other land transportation, by subject characteristic $(n=15,894)$

\begin{tabular}{|c|c|c|c|c|c|}
\hline \multirow{3}{*}{ Characteristic } & \multicolumn{4}{|c|}{ Severity of injury } & \multirow{3}{*}{ p value } \\
\hline & \multicolumn{2}{|c|}{$\begin{array}{c}\text { Motorcycles } \\
(n=13,524)\end{array}$} & \multicolumn{2}{|c|}{$\begin{array}{l}\text { Other land transportation } \\
\qquad(\mathrm{n}=\mathbf{2 , 3 7 0 )}\end{array}$} & \\
\hline & $\begin{array}{l}\text { Severe } \\
\text { n }(\%)\end{array}$ & $\begin{array}{l}\text { Not Severe } \\
\text { n }(\%)\end{array}$ & $\begin{array}{l}\text { Severe } \\
\text { n (\%) }\end{array}$ & $\begin{array}{c}\text { Not Severe } \\
\text { n (\%) }\end{array}$ & \\
\hline \multicolumn{6}{|l|}{ Age (years) } \\
\hline $0-4$ & $11(6.7)$ & $152(93.3)$ & $5(3.8)$ & $128(96.2)$ & 0.309 \\
\hline $5-14$ & $120(7.8)$ & 1425 (92.2) & $41(3.4)$ & $1154(96.6)$ & $0.000 *$ \\
\hline $15-24$ & $413(8.0)$ & $4741(92.0)$ & $25(8.1)$ & 285 (91.9) & 0.915 \\
\hline $25-34$ & $239(8.4)$ & 2603(91.6) & $28(12.7)$ & $192(87.3)$ & $0.035^{*}$ \\
\hline $35-44$ & $195(9.9)$ & $1775(90.1)$ & $28(15.6)$ & $151(84.4)$ & $0.021 *$ \\
\hline $45-54$ & $134(11.5)$ & $1032(88.5)$ & $19(11.7)$ & $143(88.3)$ & 0.896 \\
\hline $55-64$ & $35(20.5)$ & $136(79.5)$ & $14(18.7)$ & $61(81.3)$ & 0.080 \\
\hline $65+$ & $1214(9.0)$ & $12309(91.0)$ & $179(7.6)$ & $2190(92.4)$ & 0.863 \\
\hline \multicolumn{6}{|l|}{ Sex } \\
\hline Male & $887(9.7)$ & 8234 (90.3) & $122(8.2)$ & $1370(91.8)$ & 0.065 \\
\hline Female & $327(7.4)$ & $4076(92.6)$ & $57(6.5)$ & $822(93.5)$ & 0.355 \\
\hline \multicolumn{6}{|l|}{ Educational level } \\
\hline Low & $513(9.3)$ & $4998(90.7)$ & $110(6.1)$ & $1700(93.9)$ & $0.000^{*}$ \\
\hline Middle & $638(8.8)$ & $6653(91.2)$ & $58(11.4)$ & $452(88.6)$ & 0.053 \\
\hline High & $63(8.7)$ & $659(91.3)$ & $9 \quad(18.4)$ & $40(81.6)$ & 0.081 \\
\hline \multicolumn{6}{|l|}{ Employment } \\
\hline Unemployed & $499(8.7)$ & $5207(91.3)$ & $68(6.9)$ & $923(93.1)$ & 0.055 \\
\hline $\begin{array}{l}\text { Employed } \\
\text { (government, private } \\
\text { business, police) }\end{array}$ & $186(9.0)$ & $1874(91.0)$ & $18(13.1)$ & $119(86.9)$ & 0.126 \\
\hline Entrepreneur & $165(9.4)$ & $1592(90.6)$ & $25(15.8)$ & $133(84.2)$ & $0.017^{*}$ \\
\hline $\begin{array}{l}\text { Farmer, laborer, } \\
\text { fishermen }\end{array}$ & $272(9.2)$ & $2680(90.8)$ & $41(13.6)$ & $261(86.4)$ & $0.018 *$ \\
\hline Other & $45(9.5)$ & $427(90.5)$ & $5(8.9)$ & $51(91.1)$ & 1.000 \\
\hline $\begin{array}{l}\text { Not yet employed } \\
\text { (children) }\end{array}$ & $47(8.2)$ & $529(91.8)$ & $21(2.9)$ & $706(97.1)$ & $0.000 *$ \\
\hline \multicolumn{6}{|l|}{ Economic status } \\
\hline Quintile 1 & $123(8.8)$ & $1274(91.2)$ & $22(8.1)$ & $250(91.9)$ & 0.814 \\
\hline Quintile 2 & $205(8.8)$ & $2132(91.2)$ & $34(7.5)$ & $420(92.5)$ & 0.410 \\
\hline Quintile 3 & $284(9.3)$ & $2779(90.7)$ & $39(7.3)$ & $494(92.7)$ & 0.163 \\
\hline Quintile 4 & $347(9.1)$ & 3466 (90.9) & $34(5.4)$ & $592(94.6)$ & $0.002 *$ \\
\hline Quintile 5 & $255(8.7)$ & $2660(91.3)$ & $48(9.9)$ & $435(90.1)$ & 0.389 \\
\hline
\end{tabular}

*Legend: Low educational level: no schooling, elementary school, and junior high school; Middle educational level: Senior high school; High educational level: academy/tertiary education

The health status in the advanced analysis was the health condition of the respondents of having a disease or ill-health. The diseases or ill-health in question were those suspected of being associated with the injury, i.e. stroke, coronary heart disease, and vision and hearing impairments. The differences in the proportions of severity of injury due to motorcycles and other land transportation by health status are presented in Table 3.

The health status that was suspected to be associated with severity of injury comprised history of stroke, coronary heart disease, and impairment of the special senses (hearing and vision). The health status that showed a significant difference $(p<0.05)$ in the severity of the injury was impairment of vision only. However, for impairment of vision the proportion of severity of the injury was even higher in other land transportation modes as compared with motorcycles.

The severity of injury due to land transportation was differentiated into 2 groups based on transportation mode, i.e. severity of 
Table 3. Differences in severity of injury due to motorcycles and other land transportation, by health status $(\mathrm{n}=15,894)$

\begin{tabular}{|c|c|c|c|c|c|}
\hline \multirow{3}{*}{ Health status } & \multicolumn{4}{|c|}{ Severity of injury } & \multirow{3}{*}{$p$ value } \\
\hline & \multicolumn{2}{|c|}{ Motorcycles } & \multicolumn{2}{|c|}{ Other land transportation } & \\
\hline & $\begin{array}{l}\text { Severe } \\
\text { n }(\%)\end{array}$ & $\begin{array}{c}\text { Not Severe } \\
\text { n }(\%)\end{array}$ & $\begin{array}{l}\text { Severe } \\
\text { n }(\%)\end{array}$ & $\begin{array}{c}\text { Not Severe } \\
\text { n }(\%)\end{array}$ & \\
\hline \multicolumn{6}{|l|}{ Stroke } \\
\hline Yes & $10(23.3)$ & $33(76.7)$ & $1(14.3)$ & $6(85.7)$ & 1.000 \\
\hline No & $1,204(8.9)$ & $12,277(91.1)$ & $177(7.5)$ & $2,186(92.5)$ & 0.023 \\
\hline \multicolumn{6}{|c|}{ Coronary heart disease } \\
\hline Yes & $8(11.9)$ & $59(88.1)$ & $1(11.1)$ & $8(88.9)$ & 1.000 \\
\hline No & $1,206(9.0)$ & $12,252(91.0)$ & $177(7.5)$ & $2,184(92.5)$ & 0.021 \\
\hline \multicolumn{6}{|c|}{ Impairment of hearing } \\
\hline Yes & $56(11.6)$ & $427(88.4)$ & $9(8.4)$ & $98(91.6)$ & 0.397 \\
\hline No & $1,158(8.9)$ & $11,883(91.1)$ & $170(7.5)$ & $2,094(92.5)$ & 0.033 \\
\hline \multicolumn{6}{|l|}{ Impairment of vision } \\
\hline Yes & $311(10.2)$ & $2,734(89.8)$ & $58(13.7)$ & $366(86.3)$ & $0.035^{*}$ \\
\hline No & $903(8.6)$ & $9576(91.4)$ & $121(6.2)$ & $1,826(93.8)$ & 0.000 \\
\hline
\end{tabular}

*Legend: Variables stroke and coronary heart disease from 15 yr upwards, variables impairment of hearing and impairment of vision from 6 yr upwards

injury due to motorcycles and that due to other land transportation. The determinants of severity of the injury that were entered as variables in the multivariate analysis were the variables with $\mathrm{p}<0.250$. Determinants contributing to the severity of injury due to motorcycles as compared with other land transportation are presented in Table 4.

The severity of injury due to motorcycles as compared with other land transportation was influenced by age and sex. The motorcycle transportation mode had a 1.1-fold higher risk (AOR) (95\% CI: 1.0-1.3) for severe injury as compared with other land transportation modes, after adjustment for age and sex. These results may be interpreted to mean that the probability of an individual to experience severe motorcycle injury was $52.4 \%$. The factor of age had a relatively large contribution to the severity of injury due to motorcycles. The results of the multivariate analysis showed that the risk (odds ratio) of having severe injury increased with age.

Table 4. Determinants of the severity of injury due to motorcycles as compared with other land transportation

\begin{tabular}{|c|c|c|c|c|}
\hline \multirow[b]{2}{*}{ Determinant } & \multicolumn{4}{|c|}{ Severity of injury } \\
\hline & $\begin{array}{c}\text { Crude odds } \\
\text { ratio }\end{array}$ & $\begin{array}{c}\text { 95\% Confidence } \\
\text { Interval }\end{array}$ & $\begin{array}{c}\text { Adjusted } \\
\text { odds ratio }\end{array}$ & $\begin{array}{c}\mathbf{9 5 \%} \text { Confidence } \\
\text { Interval }\end{array}$ \\
\hline \multicolumn{5}{|l|}{ Mode of transportation } \\
\hline Motorcycles & 1.3 & $1.1-1.6$ & 1.1 & $1.0-1.3$ \\
\hline Other land transportation & 1 & Reference & 1 & Reference \\
\hline \multicolumn{5}{|l|}{ Age (years) } \\
\hline $0-4$ & 1 & Reference & 1 & Reference \\
\hline $5-14$ & 1.1 & $0.7-1.9$ & 1.1 & $0.6-1.9$ \\
\hline $15-24$ & 1.6 & $0.9-2.6$ & 1.5 & $0.9-2.5$ \\
\hline $25-34$ & 1.7 & $1.0-2.9$ & 1.6 & $0.9-2.7$ \\
\hline $35-44$ & 2.1 & $1.2-3.5$ & 1.9 & $1.1-3.3$ \\
\hline $45-54$ & 2.3 & $1.4-3.9$ & 2.2 & $1.3-3.7$ \\
\hline $55-64$ & 2.9 & $1.7-5.1$ & 2.8 & $1.6-4.8$ \\
\hline$\geq 65$ & 4.7 & $2.6-8.7$ & 4.3 & $2.4-7.9$ \\
\hline \multicolumn{5}{|l|}{ Sex } \\
\hline Male & 1.3 & $1.2-1.5$ & 1.3 & $1.2-1.5$ \\
\hline Female & 1 & Reference & 1 & Reference \\
\hline
\end{tabular}


In the age group of $\geq 65$ years, the risk for severe injury due to motorcycles was 4.3 times greater than in the age group of $0-4$ years $(\mathrm{OR}=4.3 ; 95 \%$ CI: 2.4-7.9). Sex was also a determinant of severity of injury due to motorcycles . Males had a 1.3-fold higher risk of having a severe injury (95\% CI: $1.2-1.5)$ as compared with females, or the probability for severity of the injury was $56.5 \%$.

\section{DISCUSSION}

The present study demonstrated that injury due to motorcycles is more severe than that due to other land transportation modes. The motorcycle transportation mode accounts for the largest proportion of land transportation injury. The 2013 data of the National Traffic Management Center (NTMC) ${ }^{(22)}$ of the Indonesian Police (Polri) comprise information that motorcycles are still the transportation mode most frequently involved in accidents, i.e. 119,568 out of 168,000 cases $(71.17 \%)$ as compared with other transportation modes. The number of severely wounded victims of accidents is reportedly 5000 cases $(2.9 \%)$. $^{(22)}$ This situation is similar to that in Malaysia, where $70 \%$ of accident victims are motorcycle drivers. ${ }^{(10)}$

The results of our study showed that in general the proportion of severity of injury due to land transportation was $8.8 \%$. Based on transportation mode, it is apparent that the proportion of severity of injury due to motorcycles was significantly higher as compared with other land transportation modes. These results showed that the proportion of severity of injury was far higher as compared with the data on severity (severe wounds) of the police, because the assessment of severity was based only on observation of the condition of the victims by police officers at the scene of an accident (Tempat Kejadian Perkara, TKP). The difference lies in the evaluation of the severity of an injury, in that the assessment performed by police officers at the TKP was by physical examination only, whereas in our analysis the severity of the injury was determined based on medical diagnostic criteria, i.e. according to the ICD-10 criteria.

The proportion of severity of injury due to motorcycles was higher in the groups of respondents of age 5-14 years, male, of low education, and with economic status at quintile 4. The proportion of severity of injury in the age group of 5-14 years was higher for the motorcycle transportation mode as compared with other land transportation modes. The results of our analysis cannot be compared with the police data, where the majority of the victims of land transportation accidents are dominated by the age group of 16-30 years and lack information on the severity of injury. ${ }^{(22)}$ The severity of injury due to traffic accidents is significantly associated with the age of the drivers. ${ }^{(23)}$ The results of a study on the registry of injuries due to motorcycle accidents in Fatmawati Central General Hospital showed the age range of the majority of victims to be 21-30 years, ${ }^{(24)}$ but data on severity were not reported. Meanwhile, the results of advanced analysis of Riskesdas 2007 data on injury due to traffic accidents also showed a wider age range for the majority of victims, i.e. 15-59 years and there were no reports yet on categories of severity of injury. This was due to the fact that in Riskesdas 2007 there was no differentiation between motorcycle accidents and accidents due to other land transportation modes. ${ }^{(25)}$

The proportion of severity of injury was more frequent in males and in children (not yet employed). The results of a study in developing countries show that accident victims are predominantly males. ${ }^{(26)}$ These results are consistent with those of a study in Kenya, where the ratio of males to females with injury due to motorcycles was $3.4: 1$. Males are at higher risk for severe injury because the majority are motorcycle riders. ${ }^{(15)}$ Originating from a younger age group, males are more frequently involved in traffic accidents than do females, i.e. around $77 \%$. Around $89 \%$ of deaths and severe injuries 
experienced by males are caused by motorcycle accidents. ${ }^{(26)}$ According to economic level by quintile, apparently the proportion of severity of injury due to motorcycles was higher as compared with other land transportation modes in the quintile 4 groups (middle economic status). These results are similar to those from India, where motorcycle injury was more frequent in the groups of middle and high economic status. ${ }^{(27)}$ The present study also showed that severity of injury is associated with health status. The results of our advanced analysis showed that impairment of vision contributed to a higher proportion of severity even in accidents due to other land transportation as compared with motorcycles $(p<0.05)$. The results of a Taiwanese study report that poor health conditions had a 1.68-fold higher risk for severe injury. Bad or less favorable health conditions potentially increase the risk of more severe injury. ${ }^{(28)}$

The results of our multivariate analysis showed that severity of injury due to motorcycles was higher as compared with severity due to other land transportation after adjustment for sex and age. Injury due to motorcycles had a 1.3-fold more severe $(\mathrm{OR}=1.3 ; 95 \% \mathrm{CI}: 1.1-1.6)$ and a 1.1-fold higher adjusted odds ratio $(\mathrm{AOR}=1.1 ; 95 \% \mathrm{CI}$ 1.0-1.3) as compared with with the odds ratios for other land transportation after adjustment for sex and age. These results may be interpreted as showing that the probability of an individual having severe injury due to motorcycles was $52.5 \%$. These results are in line with an Australian study, where injury due to motorcycles have a 29-fold higher degree of severity and a 37-fold fatality rate as compared with injury due to other types of vehicles. ${ }^{(29,30)}$ The severity of injury due to motorcycles has the highest rank of hospital visits of $79.9 \%$, followed by injury due to car accidents of $10.7 \%$ and other land transportation modes of $9.4 \% \cdot{ }^{(31)}$ The victims of motorcycle accidents also experience a trauma rate of $64.9 \%$. $^{(32)}$ Motorcycle riders have a 26-fold higher risk of death and a 5-fold higher risk of injury as compared with car drivers and passengers. In the US in 2013 it was found that the fatality rate of injury due to motorcycles was 6 times greater than that due to cars. ${ }^{(16)}$ The results of a study in Finland in 2000 and 2012 showed that the number of motorcycles increased up to $170 \%$ and $186 \%$, respectively. ${ }^{(33)}$ Motorcycle crashes are 37 times more lethal than automobile crashes. ${ }^{(34)}$

The determinants of severity of injury due to motorcycles are age and sex. The determinant of age showed that aging increases the risk of severe motorcycle injury, with the highest risk experienced by those aged $\geq 65$ years. This may be due to physiological changes in aging that result in longer reaction or perception times, resulting in delayed driving behavior of older persons, so that they become at risk for more severe injury. ${ }^{(35)}$ The results of a Wisconsin study report that injury due to motorcycles was more severe for older riders. ${ }^{(23)}$

Our study has several limitations such as the unequal completeness of the data for all variables. There are several variables such as employment that were asked only to respondents who were 15 years old and above. The criteria of severity were limited to the number of injured body parts without information on length of hospitalization due to the injury. This was due to the fact that the available data on length of hospitalization consisted of the total length of hospitalization of all injuries experienced during one year, whereas the collected data on injury were limited to the most severe injury according to the statements of the respondents. The concept of causality (cause-and-effect) between risk factors/determinants that antedate the outcome (severity) cannot be explained in this analysis due to the cross-sectional design of the Riskesdas (risk factors and outcomes viewed in the same time period). The factors of vehicles, environment, and behavior of drivers were not collected in the Riskesdas so that the present study was unable to consider these contributing factors.

The clinical implications of the severity of injury due to motorcycles and other land transportation modes are that it may result in disability and premature or early death that 
should be preventable. Disability may decrease productivity. Early death may reduce the life expectancy of an individual who may actually have a long lifespan. The results of an epidemiological study state that $13 \%$ of subjects who survive a land transportation accident experiences post-traumatic stress. ${ }^{(12)}$ However, the results of our study suggest that further studies should be done that are focused on persons of age 65 years and over. The factors associated with elderly traffic injuries in Indonesia should also be explored further.

\section{CONCLUSIONS}

Injury due to motorcycles is more severe as compared with other land transportation. For motorcycle riders, there is a need to increase the safety of driving and to be more discriminating in the selection of safer land transportation modes, by taking age and sex into consideration.

\section{CONFLICT OF INTEREST}

There was no conflict of interest for this article.

\section{ACKNOWLEDGMENT}

The authors extend their utmost gratitude to Prof. Dr. Bastaman Basuki, MPH, SpKP and dr. Iwan Ariawan, MS for their cooperation in the analysis team by providing input, guidance, and counseling so that this article could be wellorganized.

\section{CONTRIBUTORS}

WRD contributed to the idea for this article, the technical points of data analysis, and writing of the manuscript draft. DPTH contributed to data collection and analysis. STD contributed to revising the manuscript. All authors read and approved the final draft of the manuscript.

\section{REFERENCES}

1. Mathers CD, Loncar D. Projections of global mortality and burden of disease from 2002 to 2030 , PloS Med 2006;3:e442. doi: 10.1371/journal.pmed. 0030442.

2. Peden M, Scurfield R, Sleet D, et al. World report on road traffic injury prevention, World Health Organization: Geneva;2004.

3. Gosselin RA. The increasing burden of injuries in developing countries direct and indirect consequences. Tech Orthop 2009;24:230-2. doi: 10.1097/BTO.0b013e3181bfd56c.

4. Naci H, Chisholm D, Baker TD. Distribution of road traffic deaths by road user group: a global comparison. Inj Prev 2009;15:55-9. doi: 10.1136/ ip.2008.018721.

5. Thwee PP, Kanitpong K, Piyapong J. Road crashes and poverty in Myanmar: Yangon case study. J Eastern Asia Soc Transportation Stud 2013;9:12-6.

6. Badan Penelitian dan Pengembangan Kesehatan Kementerian Kesehatan RI. Laporan nasional Riskesdas tahun 2007 Jakarta : Badan Penelitian dan Pengembangan Kesehatan Kementerian Kesehatan RI;2008.

7. Badan Penelitian dan Pengembangan Kesehatan Kementerian Kesehatan RI. Laporan nasional Riskesdas tahun 2013. Jakarta: Badan Penelitian dan Pengembangan Kesehatan Kementerian Kesehatan RI;2014.

8. Wedagama D, Dissanayake D. Analysing motorcycle injuries on arterial roads in Bali using multinomial logit model. J Eastern Asia Soc Transportation Stud 2010;8:1892-1904.

9. Galukande M, von Schreeb J, Wladis A. Essential surgery at the district hospital: a retrospective descriptive analysis in three African countries. PLoS Med 2010;7:e1000243. https://doi.org/ 10.1371/journal.pmed.1000243.

10. Rahman A, Baharuddin A, Mohamad S. Burden of motorcycle-related injury in Malaysia. Int J Emerg Med 2015;8:17. doi: 10.1186/s12245-0150065-4.

11. Ngunu CN. Factors determining of injury severity among motorcycle crash victims attending Thika level 5 hospital, Klambu county 2013. [thesis]. Kenya: Jomo Kenyatta University of Agriculture and Technology;2015.

12. Hattis R, Law M. The five stages of prevention: a practical new classification for health planning and clinical practice. Loma Linda, California;2013.

13. Adoga A, Ozoilo N. The epidemiology and type of injuries seen at the accident and emergency unit of a Nigerian referral center. J Emerg Trauma 
Shock 2014;7:77-82. doi: 10.4103/0974-2700. 130875.

14. Phillipo L, Joseph B, Isidor H, et al. Motorcycle injuries as an emerging public health problem in Mwanza city, Tanzania: a call for urgent intervention. Tanzanian J Health Res 2010;2:13-7. http://dx.doi.org/10.431.4/thrb.v12i4.55500.

15. Lin MR, Kraus JF. A review of risk factors and patterns of motorcycle injuries. Accid Anal Prev 2009;41:710-22. doi: 10.1016/j.aap.2009.03.010.

16. National Highway Traffic Safety Administration U.S. Department of Transportation. Traffic safety facts: Fatality Analysis Reporting System (FARS) Annual Report. Washington, DC: U.S. Department of Transportation;2013.

17. World Health Organization. International statistical classification of diseases and related health problems. $10^{\text {th }}$ Revision. Instruction Manual. Geneva: World Health Organization. Geneva;2011.

18. Lemeshow S, Hosmer DW, Klar J, Lwanga SK, Adequacy of sample size in health studies. New York: John Wiley\& Son; 1990.

19. Badan Penelitian dan Pengembangan Kesehatan Kementerian Kesehatan R.I. Pedoman wawancara Riskesdas tahun 2013. Jakarta: Badan Penelitian dan Pengembangan Kesehatan Kementerian Kesehatan R.I.; 2014.

20. World Health Organization. Health statistics and information systems: global health estimates. Geneva: World Health Organization;2011.

21. Badan Penelitian dan Pengembangan Kesehatan Kementerian Kesehatan R.I. Laporan biomedis Riskesdas tahun 2013. Jakarta: Badan Penelitian dan Pengembangan Kesehatan Kementerian Kesehatan R.I.; 2014.

22. National Traffic Management Center (NTMC). Laporan tahunan: Polantas dalam angka tahun 2013. Jakarta: National Traffic Management Center;2013.

23. Hanrahan RB, Layde PM, Zhu S, et al. The association of driver age with traffic injury severity in Wisconsin. Traffic Inj Prev 2009; 10:3617. doi: 10.1080/15389580902973635.

24. Riyadina W, Subik IP. Keparahan cedera pada korban kecelakaan sepeda motor di Instalasi Gawat Darurat RSUP Fatmawati. Univ Med 2007;26:64-72. DOI: http://dx.doi.org/10.18051/ UnivMed.2007.v26.64-72.
25. Riyadina W, Suhardi, Permana M. Pola dan determinan sosiodemografi cedera akibat kecelakaan lalu lintas di Indonesia. Maj Kedokt Indon 2009;59:464-72.

26. World Health Organization. Global status report on road safety. Geneva: World Health Organization; 2013.

27. Gharde PM, Quazi SZ, Wagh VV, Road traffic accident victims socio-demographic profiles: a community-based study in Central India. Int J Comm Med Public Health 2017; 4:3819-24. DOI: http://dx.doi.org/10.18203/2394-6040. ijcmph20174257.

28. Yiengprugsawan V, Stephen K, McClure R, et al. Risk factors for injury in a national cohort of 87.134 Thai adults. Public Health 2012;126: 33-9. doi: 10.1016/j.puhe.2011.09.027.

29. Department of Infrastructure, Transport, Regional Development and Local Government. Road deaths Australia 2008 statistical summary. Road safety report No. 4. Canberra: Department of Infrastructure, Transport, Regional Development and Local Government.; 2009.

30. Henley G, Harrison JE. Serious injury due to land transport accidents, Australia, 2006-07. Canberra: Australian Institute of Health and Welfare; 2009.

31. Sethi D, Aljunid S, Saperi SB, et al. Comparison of the effectiveness of trauma services provided by secondary and tertiary hospitals in Malaysia. Ann Emerg Med 2007;49:52-61. https://doi.org/ 10.1016/j.annemergmed.2006.08.019.

32. Sabariah FJ, Ramesh N, Mahathar AW. National trauma database (NTrD)-improving trauma care: first year report. Med J Malaysia 2008;63(Suppl C):45-9.

33. Transport and Tourism Statistics Finland. Statistics on road traffic accidents in 2012. Helsinki: Transport and Tourism;2013.

34. MacLeod JBA, DiGiacomo JC, Tinkoff G. An evidence-based review: helmet efficacy to reduce head injury and mortality in motorcycle crashes: EAST practice management guidelines. J Trauma Acute Care Surg 2010;69:1101-11. doi: 10.1097/ TA.0b013e3181f8a9cc.

35. Pour-Rouholamin M, Jalayer M. Analyzing the severity of motorcycle crashes in North Carolina using highway safety information systems data. ITE J 2016:45-9. 